\begin{tabular}{|c|c|c|}
\hline \multirow{3}{*}{$\begin{array}{r}\text { Case Reports in } \\
\text { Gastroenterology }\end{array}$} & \multirow{2}{*}{\multicolumn{2}{|c|}{ Case Rep Gastroenterol 2018;12:646-652 }} \\
\hline & & \\
\hline & $\begin{array}{l}\text { DOI: } 10.1159 / 000493182 \\
\text { Published online: November 14, } 2018\end{array}$ & $\begin{array}{l}\text { (c) } 2018 \text { The Author(s) } \\
\text { Published by S. Karger AG, Basel } \\
\text { www.karger.com/crg }\end{array}$ \\
\hline & $\begin{array}{l}\text { This article is licensed under the } \mathrm{Cr} \\
\text { International License (CC BY-NC) (ht } \\
\text { Usage and distribution for commercial }\end{array}$ & $\begin{array}{l}\text { nons Attribution-NonCommercial } 4.0 \\
\text { ger.com/Services/OpenAccessLicense). } \\
\text { uires written permission. }\end{array}$ \\
\hline
\end{tabular}

\title{
Giant Left-Sided Amyand's Hernia: A Challenging Procedure in a Rural Hospital
}

\author{
Reno Rudiman ${ }^{a}$ Andika A. Winata ${ }^{b}$ \\ aDigestive Surgery Department, Padjadjaran University, Hasan Sadikin Hospital, \\ Bandung, Indonesia; 'burgery Department, Bengkayang District General Hospital, \\ Bengkayang, Indonesia
}

\section{Keywords}

Giant inguinal hernia · Amyand's hernia · Appendectomy · Omentectomy

\begin{abstract}
The finding of a vermiform appendix in the case of an inguinal hernia that extends below the midpoint of the inner thigh when the patient is in a standing position is defined as giant leftsided Amyand's hernia. It is a very rare case and significantly challenging in terms of preoperative diagnosis and surgical management. Here we present our experience with a case of a giant left-sided Amyand's hernia that was followed up for 2 months.
\end{abstract}

(C) 2018 The Author(s)

Published by S. Karger AG, Basel

\section{Introduction}

Repair of inguinal hernia is one of the most frequent surgical procedures that a surgeon faces [1]. A giant inguinal hernia is defined as an inguinal hernia that extends below the midpoint of the inner thigh when the patient is in a standing position [2]. This hernia is rare and usually the result of negligence or fear of surgical procedures and is prevalent in the rural population [1]. No treatment has been adopted as a standard procedure. As a result, choosing a surgical procedure is made difficult and the decision must be made intraoperatively [2]. 
The finding of a vermiform appendix in the case of an inguinal hernia is called Amyand's hernia [3]. This unusual situation is estimated to occur in approximately $1 \%$ of adult inguinal hernia cases with an incidence 12 times greater in males [3,4]. Most cases of Amyand's hernia occur on the right side. A left-sided Amyand's hernia is a rare occurrence [5]. Here, we present a patient with a giant left-sided Amyand's hernia where simple reduction was successful, with a literature review.

\section{Case Report}

A 53-year-old male patient, coming from Sanggau Ledo, West Borneo, Indonesia, sought medical assistance at Bengkayang General Hospital (a small hospital in a rural area near Malaysia's border). He had a history of a left inguinal mass for almost 40 years which decreased but increased again with physical exertion. This lump was large in size, around $24 \times 18 \mathrm{~cm}$, irreducible to digital maneuvers within this 4 months, without the presence of inflammatory signs (Fig. 1). After a thorough examination, it was diagnosed as left irreducible indirect inguinal hernia without obstruction and with no sign of gangrenous tissue. The patient had no significant comorbidities. He was taken up for surgery after all necessary investigations and preanesthetic assessment.

He underwent an elective tension-free hernia repair and appendectomy using an oblique incision in the left inguinal region under the spinal block. Intraoperatively an indirect sac was found and dissected free of cord structures. On opening, a small bowel was revealed as well as mobilized cecum, noninflammation appendix, and colon as content. There were flimsy adhesions of the cecum and appendix with the sac of the hernia. The adhesions were gently broken, and the content was reduced. We did lateral extension of the internal ring and partial omentectomy. Manual reduction was then attempted, and it was possible to reduce the contents into the abdominal cavity. Intra-abdominal pressure was measured and confirmed by the intravesicular technique (18 $\mathrm{mm} \mathrm{Hg}$ ). The internal ring was repaired with interrupted polypropylene \#2/0. Lichtenstein's tension-free technique was performed with polypropylene mesh. Hemostasis was checked (Fig. 2, 3). The patient was transferred to the recovery room in a stable condition. There were no signs of abdominal compartment syndrome and cardiorespiratory event postoperatively. He remained comfortable over 2 months of follow-up.

\section{Discussion}

The first description of an appendix in an inguinal hernia is attributed to Amyand (sergeant surgeon to King George I and II) who, in 1735, found a perforated appendix in an 11year-old boy who presented with a right inguinal hernia and fecal fistula [6]. Right-sided Amyand's hernias occur more often than left-sided ones due to the anatomical location of the appendix on the right [7]. In 2003, D'Alia et al. [8] reported an incidence of just $0.08 \%$ of inguinal hernias in 1,341 patients over a 13-year period in the Messina University Hospital or less than $0.6 \%$ according to Michalinos et al. [9]. It is, as expected, more common in male patients and presents a bimodal age distribution in neonates and in patients aged $>70$ years [9]. Left-sided Amyand's hernias are very rare; a literature review revealed only 15 reported cases of left-sided Amyand's hernias [6]. The presence of left-sided Amyand's hernias has been attributed to situs inversus, malrotation, a mobile cecum, and an excessively long appendix $[5,6]$. 


\section{Case Reports in Gastroenterology}

Case Rep Gastroenterol 2018;12:646-652

DOI: 10.1159/000493182

(c) 2018 The Author(s). Published by S. Karger AG, Basel www.karger.com/crg

Rudiman and Winata: Giant Left-Sided Amyand's Hernia: A Challenging Procedure in a Rural Hospital

Amyand's hernia is commonly misdiagnosed as an ordinary incarcerated hernia. Symptoms mimicking appendicitis may occur in right-sided Amyand's hernia [10]. The majority of these cases present with the features of an obstructed or strangulated inguinal hernia or with or without features of appendicitis $[3,4,6]$. It is difficult to diagnose clinically and is rarely diagnosed preoperatively [3]. Usually it is diagnosed intraoperatively. In some reported cases, preoperative diagnosis was made by ultrasound or CT scanning [5]. Laermans et al. [11] in 2007 reported only two cases where diagnosis was established prior to surgery. Bradley et al. [12] in 2003 also stated that ultrasound can accurately diagnose indirect groin hernias (sensitivity $97 \%$, specificity $87 \%$ ). Preoperative diagnosis in this unusual condition is difficult. Weber was the only surgeon who reported making the correct diagnosis preoperatively [13]. In our case, the patient did not show any obstruction or strangulated signs and the diagnosis was established intraoperatively because the use of ultrasound is not routine to confirm the diagnosis and CT scan is not available here.

In 2007, Losanoff and Basson [14] proposed a classification when facing this rare condition. In Amyand's hernia type 1, since there is an incidental finding of a normal appendix in the hernial sac with no associated inflammation of organ, no resection of cecal appendix is recommended nor reduction of sac contents with hernioplasty with prosthetic polypropylene mesh. On the other hand, Abu-Dalu and Urcra [15] had suggested an appendectomy because appendix becomes more vulnerable to trauma in Amyand's hernia and is ultimately retained by adhesions. Its blood supply may subsequently be cut off or significantly reduced, resulting in inflammation and bacterial overgrowth. Johari et al. [16] suggested that appendectomies for left-sided hernias be routinely performed irrespective if inflamed or not, as a future appendicitis may pose a diagnostic doubt due to the position of the appendix. In this patient, we found a mobilized cecum and ascending colon allowing facile advancement of the appendix into the hernial sac with a flimsy adhesion. We prefer to do a tension-free hernia repair using a mesh with an appendectomy and partial omentectomy.

Giant inguinoscrotal hernias are defined as those extending below the midpoint of the inner thigh, in the standing position. They are common in rural populations. Patients would typically present with voiding difficulty. Pressure wounds are common in the medial aspect of the thigh as well as the scrotum. As shown on preoperative pictures, the penis is buried inside the scrotum. The social impact is significant, which can cause social isolation, a fear of seeking medical attention, and subsequently, a worsening of the condition [1]. Specific problems associated with management of giant inguinoscrotal hernias include loss of domain, cardiorespiratory complications, need for elective postoperative ventilation, high risk for wound breakdown and recurrence, problems due to residual scrotal skin, and scrotal hematoma. Hence, the management of these hernias is challenging and needs good support from anesthetists as well [1]. Recurrence is much higher in giant inguinoscrotal hernias than other inguinoscrotal hernias. Tension-free mesh repair can reduce recurrences. Scrotal skin may be left intact because it can be used for decompression if the patient develops respiratory compromise at a later stage. Drains can be placed to avoid the risk of hematomas and wound breakdown [17].

Giant inguinal hernias are classified into three types by Trakarnsagna et al. [2]. Loss of domain of intra-abdominal cavity is one of the main problems in the management of giant inguinal hernia. Forced reduction and simple hernioplasty may not be the appropriate procedure for moderate and severely enlarged giant inguinal hernia. As these giant inguinoscrotal hernias are usually chronic, sudden replacement of the large bowel contents into the abdominal cavity causes an abrupt increase in intra-abdominal pressure. Forcing the abdominal contents back and repairing the hernia could be disastrous owing to the sudden increase in 
intraperitoneal pressure due to impaired diaphragmatic motion and reduced venous return. Because of reduced diaphragmatic movements, reduction in tidal volume, vital capacity, defects in gas exchange, and basal lung collapse leading to infection occur. Pain, paralytic ileus, and effect of anesthetic drugs further aggravate these problems in the postoperative period. Another ill effect of increased intra-abdominal pressure is the tension posed on the postoperative wound, which significantly impairs healing [1].

In these cases, a reduction in herniated viscera leads to a sudden increase in intra-abdominal and intrathoracic pressures, which then leads to respiratory compromise and is associated with high mortality. Techniques described to overcome this hardship include debulking of abdominal contents or enlarging the abdominal cavity (phrenectomy). Extensive bowel resections in the form of total or hemicolectomy, omentectomy, splenectomy, and even small bowel resections have been described. Phrenectomy is done by creating a ventral hernia and using high-density polyethylene mesh, scrotal skin flap, or component separation technique [1].

Regarding our case, he suffered from a second type of giant inguinal hernia. Its sac extends below the imaginary line at the lower thigh but above the line between superior borders of patellar bone. We performed partial omentectomy, appendectomy, and hernioplasty to reduce postoperative intra-abdominal pressure. Most cases of this second type of giant inguinal hernia require additional procedures rather than simple hernioplasty alone except only one case reported by Coetzee et al. [17].

In conclusion, giant left-sided Amyand's hernia is a rare case (only 15 reported cases in the literature review). Preoperative diagnosis in this unusual condition is difficult. Ultrasonography has an important role to diagnose indirect groin hernias with a sensitivity of $97 \%$ and a specificity of $87 \%$. No treatment has been adopted as standard procedure, but most cases require more than 1 additional procedures to reduce intra-abdominal pressure.

\section{Acknowledgement}

We would like to show our gratitude to Grace Ika Yuwono of the University of Sydney for her writing assistance and language editing.

\section{Statement of Ethics}

The authors have no ethical conflicts to disclose. Written consent from the subject of this case report has been obtained.

\section{Disclosure Statement}

The authors have no conflicts of interest to declare.

\section{Funding Sources}

There are no funding sources to be mentioned. 


\section{Case Reports in Gastroenterology}

\begin{tabular}{l|l}
\hline DOI: $10.1159 / 000493182$ & (c) 2018 The Author(s). Published by S. Karger AG, Basel
\end{tabular} www.karger.com/crg

Rudiman and Winata: Giant Left-Sided Amyand's Hernia: A Challenging Procedure in a Rural Hospital

\section{Author Contributions}

Study conception and design: A.A. Winata, R. Rudiman. Acquisition of data: A.A. Winata. Analysis and interpretation of data: A.A. Winata. Drafting of the manuscript: A.A. Winata, R. Rudiman. Critical revision: R. Rudiman.

\section{References}

1 Karthikeyan VS, Sistla SC, Ram D, Ali SM, Rajkumar N. Giant inguinoscrotal hernia - report of a rare case with literature review. Int Surg. 2014 Sep-Oct;99(5):560-4.

2 Trakarnsagna A, Chinswangwatanakul V, Methasate A, Swangsri J, Phalanusitthepha C, Parakonthun T, et al. Giant inguinal hernia: Report of a case and reviews of surgical techniques. Int J Surg Case Rep. 2014;5(11):868-72.

3 Kuru S, Bulgurcu A, Kismet K, Ertas E. Should an appendectomy be performed for the treatment of Amyand's hernia with non-inflamed vermiform appendix? A case report and review of the literature. Viszeralmedizin. 2013;29:51-4.

4 Feitosa Cavalcante J, Melo Teixeira Batista H, Cavalcante Pita Neto I, Fernandes Frutuoso J, Rodrigues Pinheiro W, Maria Pinheiro Bezerra I, et al. Amyand's Hernia with Appendicitis: A Case Report and Integrative Review. Case Rep Surg. 2015;2015:941039.

5 Al-Mayoof AF, Al-Ani BH. Left-sided amyand hernia: report of two cases with review of literature. European J Pediatr Surg Rep. 2014 Jun;2(1):63-6.

6 Mewa Kinoo S, Aboobakar MR, Singh B. Amyand's Hernia: A Serendipitous Diagnosis. Case Rep Surg. 2013;2013:125095.

7 Singhal S, Singhal A, Negi SS, Tugnait R, Arora PK, Tiwari B, et al. Amyand's Hernia: Rare Presentation of a Common Ailment. Case Rep Gastrointest Med. 2015;2015:629127.

8 D'Alia C, Lo Schiavo MG, Tonante A, Taranto F, Gagliano E, Bonanno L, et al. Amyand's hernia: case report and review of the literature. Hernia. 2003 Jun;7(2):89-91.

9 Michalinos A, Moris D, Vernadakis S. Amyand's hernia: a review. Am J Surg. 2014 Jun;207(6):989-95.

10 Pun A, Khatri R. Left sided Amyand's hernia with sliding component. JNMA J Nepal Med Assoc. 2013 JanMar;52(189):285-7.

11 Laermans S, Aerts R, De Man R. Amyand's hernia: inguinal hernia with acute appendicitis. JBR-BTR. 2007 Nov-Dec;90(6):524-5.

12 Bradley M, Morgan D, Pentlow B, Roe A. The groin hernia - an ultrasound diagnosis? Ann R Coll Surg Engl. 2003 May;85(3):178-80.

13 Weber RV, Hunt ZC, Kraal JG. Amyand's hernia: etiologic and therapeutic implications of the two complications. Surg Rounds. 1999;22:552-6.

14 Losanoff JE, Basson MD. Amyand hernia: what lies beneath - a proposed classification scheme to determine management. Am Surg. 2007 Dec;73(12):1288-90.

15 Abu-Dalu J, Urca I. Incarcerated inguinal hernia with a perforated appendix and periappendicular abscess: report of a case. Dis Colon Rectum. 1972 Nov-Dec;15(6):464-5.

16 Johari HG, Paydar S, Davani SZ, Eskandari S, Johari MG. Left-sided Amyand hernia. Ann Saudi Med. 2009 JulAug;29(4):321-2.

17 Coetzee E, Price C, Boutall A. Simple repair of a giant inguinoscrotal hernia. Int J Surg Case Rep. 2011;2(3):32-5. 


\section{Case Reports in Gastroenterology}

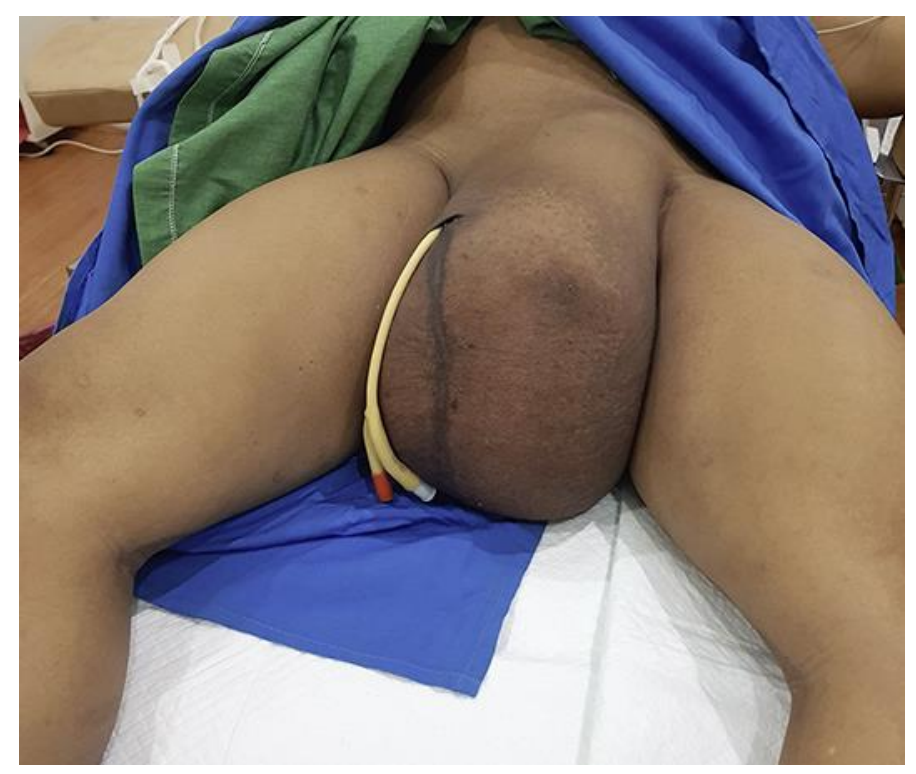

Fig. 1. Giant left-sided inguinal hernia.

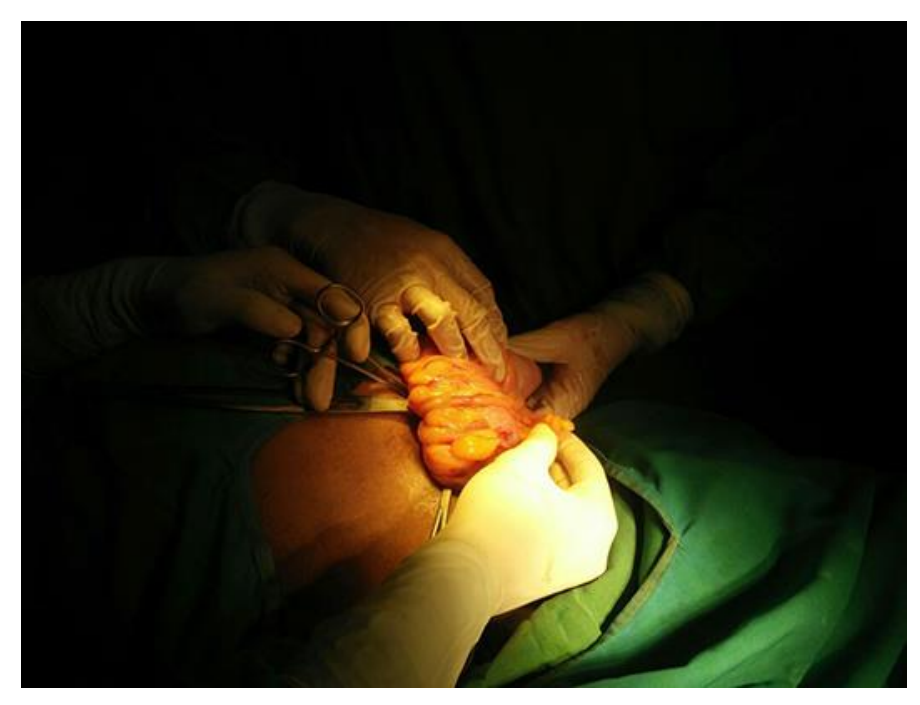

Fig. 2. Appendix was found inside the hernial sac.

Rudiman and Winata: Giant Left-Sided Amyand's Hernia: A Challenging Procedure in a Rural Hospital

(c) 2018 The Author(s). Published by S. Karger AG, Basel www.karger.com/crg 


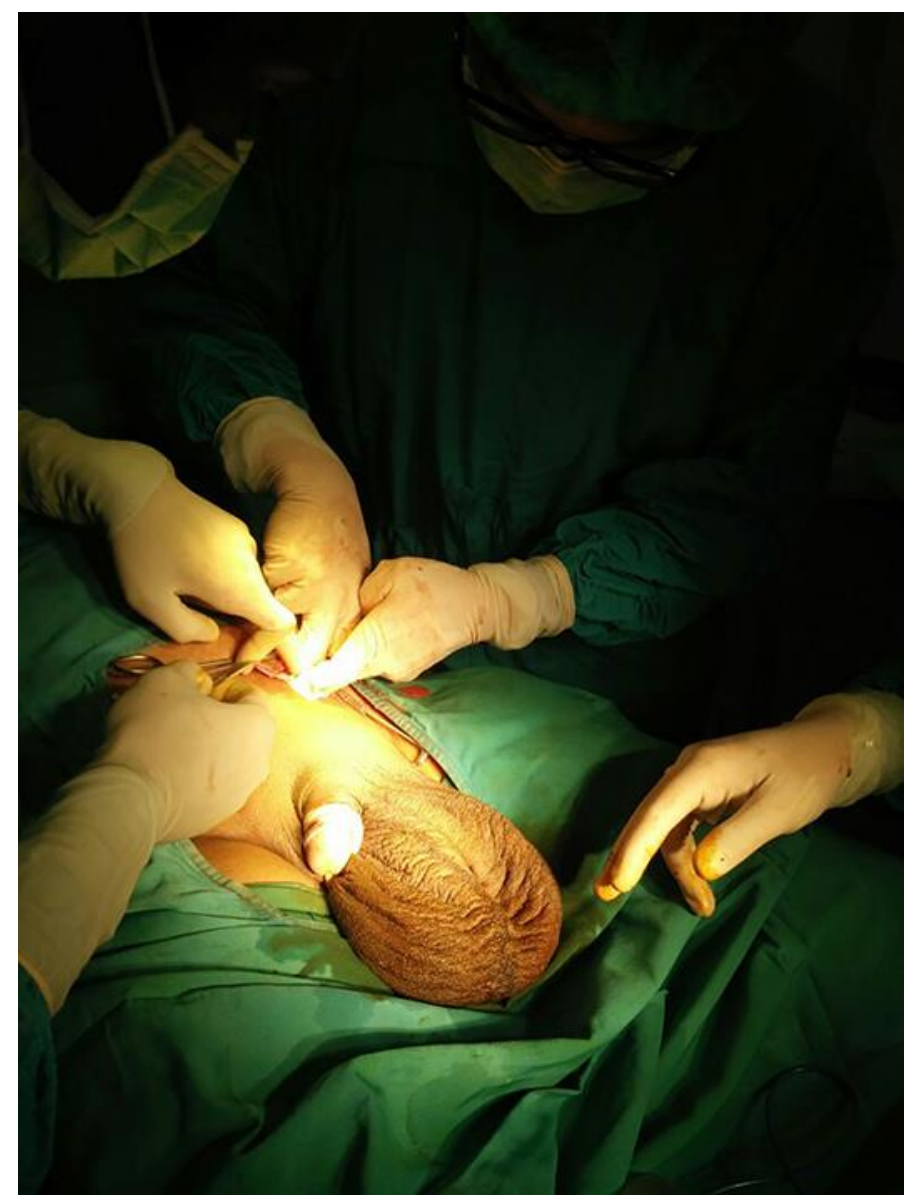

Fig. 3. After a tension-free herniorraphy.

Rudiman and Winata: Giant Left-Sided Amyand's Hernia: A Challenging Procedure in a Rural Hospital (c) 2018 The Author(s)
www.karger.com/crg 